НАУКОВИЙ ВІСНИК

Scientific messenger of Lviv National University

$\longrightarrow$

(1)

СЕРя "СльььКогосподАРСЬК НАУК

Том 22 № 93

2020
Науковий вісник Дьвівського національного університету ветеринарної медицини та біотехнологій імені С.3. Гжицького. Серія: Сільськогосподарські науки

Scientific Messenger of Lviv National University of Veterinary Medicine and Biotechnologies. Series: Agricultural sciences

UDC 638.144:664.162.1/.7:631.544

\title{
The effectiveness of using glucose-fructose syrup for feeding bees in under cover conditions
}

\author{
V. M. Nedashkivskyi \\ Bila Tserkva National Agrarian University, Bila Tserkva, Ukraine
}

Article info

Received 04.08.2020

Received in revised form 02.09 .2020

Accepted 03.09.2020

Bila Tserkva National Agrarian University, Soborna pl. 8/1 Bila Tserkva, 09117, Ukraine. Tel: +38-097-153-30-53 E-mail:profkom1967@ukr.net
Nedashkivskyi, V. M. (2020). The effectiveness of using glucose-fructose syrup for feeding bees in under cover conditions. Scientific Messenger of Lviv National University of Veterinary Medicine and Biotechnologies. Series: Agricultural sciences, 22(93), 10-13. doi: 10.32718/nvlvet-a9302

The beekeeping practice provides for using stimulating feeding of the bee colonies in order to accelerate their growth and development. Sugar syrup is usually used to feeding bees. Despite the obvious benefits, sugar syrup use as a feed additive which has a number of disadvantages. This is due to the different origin of such syrup (beet, sugarcane, corn, fructose syrup, etc.) and, accordingly, different effects on the physiological and metabolic processes of the body and the life of bees and their colonies as a whole. In recent years, scientific research has intensified in many countries of the world to find new substitutes for sugar syrup to feed bee colonies. One of the artificial substitutes for carbohydrate feed to bees is glucose-fructose syrup content of reducing sugars close to honey and exceed to invert syrup. Glucose-fructose syrup is produced mainly from high-quality corn starch by enzymatic hydrolysis to glucose, followed by isomerization part of glucose into fructose and subsequent purification through coal core and ion exchange resins. It contains all the essential amino acids, trace elements, $B$ vitamins, and does not require the release of a large amount of enzyme by bees, as is in the case of sugar syrup. Its use as a feed additive increases the bees life span does not lead them to expired, preserves the activity of their hypopharyngeal glands and allows to put food directly into the cells. The article presents results of the research on the effectiveness of stimulating the development of bee colonies and pollination of cucumbers in under cover conditions for using glucose-fructose syrup. It has found that for stimulating feeding of the bee colonies are used glucose-fructose syrup at the rate of $200 \mathrm{~g}$ per day in under cover conditions, against the background of the presence sufficient feed honey and bee bread in the nests, contributes to an increase the amount of brood grown by $13.5 \%(P<0.01)$ and the amount of pollen brought by them by $20.1 \%$

Key words: bee colony, stimulating feeding, glucose-fructose syrup, brood, pollen pellet.

\section{Ефективність використання глюкозо-фруктозного сиропу в годівлі бджіл в умовах закритого грунту}

\author{
В. М. Недашківський
}

Білоиерківський наиіональний аграрний університет, м. Біла Церква, Украӥна

\footnotetext{
Практика ведення бджільниитва передбачає використання стимулюючих підгодівель бджолиних сімей з метою прискорення ïх росту і розвитку. Зазвичай для підгодівлі бджіл використовують иукровий сироп. Не дивлячись на очевидні переваги, використання иукрового сиропу в якості кормової добавки має і ряд недоліків. Це зумовлено різним походженням такого сиропу (буряковий, тростинний, кукурудзяний, сироп з фруктози тощо) та, відповідно, різним впливом на фізіологічні та метаболічні проиеси організму бджіл та життєдіяльність їх сімей в иілому. Останніми роками у багатьох країнах світу активізувалися наукові дослідження щзодо пошуку нових замінників иукрового сиропу для підгодівлі бджолиних сімей. Одним із итучних замінників вуглеводних кормів для бджіл $\epsilon$ глюкозо-фруктозний сироп, який за вмістом редукуючих иукрів близький до меду $і$ перевериує інвертний сироп. Виробляють глюкозо-фруктозний сироп здебільшого з високоякісного кукурудзяного крохмалю ферментативним гідролізом його до глюкози з наступною ізомеризачією частини глюкози у фруктозу та подальшим очищенням крізь вугільні колонки й іонообмінні смоли. Він містить усі незамінні амінокислоти, мікроелементи, вітаміни групи В, не потребує виділення
} 
великої кількості ферменту бджолами, як у випадку з иукровим сиропом. Його використання, як кормової добавки, збільшує тривалість життя бджіл, не піддає їх зносу, зберігає активність їх гіпофарінгеальних залоз, дозволяє складати корм відразу в комірки. У статті представлені результати наукових досліджень, шодо вивчення ефективності стимулювання розвитку бджолиних сімей та запилення огірків в умовах закритого трунту за використання глюкозо-фруктозного сиропу. Встановлено, цио стимулююча підгодівля бджолиних сімей глюкозо-фруктозним сиропом із розрахунку 200 г на добу в умовах закритого трунту, на фоні наявності в гніздах у достатній кількості кормового меду та перги, сприяє підвищенню кількості вирощеного ними розплоду на 13,5\% (P<0,01) та кількості принесеного ними пилку 20,1\%.

Ключові слова: бджолина сім'я, стимулююча підгодівля, глюкозо-фруктозний сироп, розплід, обніжжя.

\section{Ветуп}

Ріст, розвиток та продуктивність бджолиних сімей залежить від цілого ряду факторів (Drujbiak et al., 2017; Kovalskyi et al., 2018; Kovalchuk et al., 2019). Одним із основних з них є забезпечення бджолиних сімей достатньою кількістю білкового та вуглеводного корму. Вуглеводний корм бджоли виготовляють переважно 3 нектару медоносних культур, основу якого складають глюкоза і фруктоза, окрім цього виявлено і сахарозу, мальтозу, галактозу та декстрини. Крім вищеперерахованих речовин в меді містяться азотисті речовини, мінеральні речовини, вітаміни та інші біологічно активні компоненти, кількість яких залежить від виду рослин, 3 яких бджоли збирають нектар. Встановлено, що протягом року одна бджолина сім'я споживає близько 100 кг меду (Taranov, 1986; Razanov et al., 2018; Nedashkivskyi \& Hutsol, 2020). Недостатнє забезпечення бджолиних сімей вуглеводним кормом негативно позначається на їх розвитку та продуктивності (Vishchur et al., 2016; 2019; Piven et al., 2020). Тому важливе значення в успішному веденні бджільництва $є$ безперервне надходження вуглеводного корму в бджолині гнізда протягом активного сезону. Однак, не завжди вдається створити достатній безперервний нектаро-пилконосний конвеєр, особливо ранньою весною та восени, а також в умовах закритого грунту в період запилення овочевих культур (Chergyk et al., 1972; Ponomareva, 1980; Blonskaja et al., 1990). Враховуючи дані фактори, на практиці застосовують різні замінники вуглеводного корму для бджіл. Основним замінником вуглеводного корму меду, виготовленого $з$ нектару рослин, $\epsilon$ цукровий сироп. Поряд 3 цим, необхідно відмітити, що були спроби використання березового та кавунового соку в годівлі бджіл, однак вони не знайшли широкого застосування. Тому пошук нових замінників вуглеводного корму, здатних надавати стимулювальний вплив на ріст і розвиток медоносних бджіл, $є$ перспективним напрямком у бджільництві.

Останніми роками у бджільництві спостерігається стійка тенденція до використання в годівлі бджіл глюкозо-фруктозного сиропу, який за вмістом сахарози та глюкози не поступається медові (Bilash, 2005; Nedashkivs'kyj, 2017; Razanov et al., 2019). Виробляють глюкозо-фруктозний сироп здебільшого з високоякісного кукурудзяного крохмалю ферментативним гідролізом його до глюкози з наступною ізомеризацією частини глюкози у фруктозу та подальшим очищенням крізь вугільні колонки й іонообмінні смоли. Ізомеризація глюкози у фруктозу зумовлює підвищення солодкості сиропу, адже солодкість глюкози становить тільки 65-75 \% від солодкості цукру, тоді як солодкість фруктози 140-175 \%. Тому глюкозофруктозний сироп при однаковій концентрації має дещо вищу солодкість, ніж цукровий сироп (Drobot et al., 2006).

Враховуючи, що масштаби вирощування цієї культури в Україні з року в рік стрімко зростають, а цукрового буряка, як джерела цукру, різко знижується, то перспективним може бути більш широке використання глюкозо-фруктозного сиропу в бджільництві. Утримання бджіл в умовах закритого грунту потребує постійного поповнення кормових запасів, адже тепличні культури характеризуються низькою нектаропродуктивністю, яка складає в середньому 20 кг/га, що у 2,3 рази нижче, порівняно з аналогічними культурами, що вирощені поза межами теплиці. За недостатнього надходження вуглеводного корму в бджолині сім’ї в умовах закритого грунту різко знижується інтенсивність вирощення бджолиними сім'ями розплоду, що негативного позначається як на їх силі, так i на ефективності запилення (Druzhbjak, 2013; Prudnikov, 2017).

У зв'язку з цим, метою наших досліджень було вивчення ефективності стимулювання розвитку бджолиних сімей та запилення огірків в умовах закритого грунту за використання глюкозо-фруктозного сиропу.

\section{Матеріал і методи досліджень}

Дослідження проводили в умовах закритого грунту при вирощуванні тепличних огірків. Для проведення експерименту за принципом груп-аналогів було сформовано дві групи бджолиних сімей (1 - контрольна, 2 - дослідна) української степової породи. Силу бджолиних сімей визначали по кількості вуличок зайнятих бджолами (простір між рамками який займають бджоли).

Бджолині сім'ї забезпечували вуглеводним та білковим кормом у кількості 15 кг і 1,4 кг відповідно. Бджолиним сім'ям дослідної групи протягом перебування їх у теплиці згодували на добу по 200 г глюкозо-фруктозного сиропу. На початку та по закінченню експерименту проводили підрахунок запечатуваного розплоду в бджолиних гніздах за допомогою рамкисітки. Активність запилення бджолами огірків в ізольованому просторі вивчали шляхом підрахунку принесеної бджолиної обніжки. Кожної доби протягом періоду цвітіння тепличних огірків проводили відбір обніжки за допомогою пилковловлювача загальноприйнятим способом (Polishhuk \& Gajdar, 2008). Загальну масу обніжжя, визначали за допомогою терезів ВЛА-200. Характеристика піддослідних бджолиних сімей наведена в таблиці 1. 
Таблиця 1

Характеристика піддослідних бджолиних сімей в середніх показниках по групах

\begin{tabular}{|c|c|c|c|c|c|c|}
\hline \multirow{2}{*}{$\begin{array}{c}\text { Групи піддослідних } \\
\text { бджолиних сімей }\end{array}$} & \multirow{2}{*}{$\begin{array}{c}\text { Кількість бджо- } \\
\text { линих сімей в } \\
\text { групі, шт. } \\
\end{array}$} & \multirow{2}{*}{$\begin{array}{l}\text { Порода } \\
\text { бджіл }\end{array}$} & \multirow{2}{*}{$\begin{array}{c}\text { Сила сімей, } \\
\text { кількість вуличок } \\
\text { бджіл } \\
\end{array}$} & \multirow{2}{*}{$\begin{array}{l}\text { Кількість запечата- } \\
\text { ного розплоду, см² }\end{array}$} & \multicolumn{2}{|c|}{ Кількість корму, кг } \\
\hline & & & & & вуглеводного & білкового \\
\hline Контрольна & 5 & $\begin{array}{c}\text { українська } \\
\text { степова }\end{array}$ & 6,0 & 2250 & 15,5 & 1,4 \\
\hline Дослідна & 5 & $\begin{array}{l}\text { українська } \\
\text { степова }\end{array}$ & 6,0 & 2259 & 15,0 & 1,4 \\
\hline
\end{tabular}

Результати досліджень опрацьовували стандартними методами варіаційної статистики з використанням алгоритмів Plokhynskyi (1969). При математичному опрацюванні результатів досліджень використовували ПОМ і застосовували комп'ютерні програми статистичної обробки Microsoft Excel. Різницю між групами оцінювали за критерієм Стьюдента і вважали вірогідною при значеннях: ${ }^{*}-\mathrm{P}<0,05 ;{ }^{* *}-\mathrm{P}<0,01,{ }^{* * *}-\mathrm{P}<0,001$.

\section{Результати та їх обговорення}

Аналіз результатів досліджень) показав, що ізоляція бджолиних сімей в умовах пристосованих плівкових теплицях помітно затримує розвиток бджолиних сімей (табл. 2).

\section{Таблиця 2}

Інтенсивність вирощення бджолиними сім'ями розплоду в ізольованому просторі, см², $\bar{X} \pm S_{\bar{X}}, \mathrm{n}=5$

\begin{tabular}{|c|c|c|c|c|c|c|}
\hline \multirow{2}{*}{$\begin{array}{c}\text { Група бджолиних } \\
\text { сімей }\end{array}$} & \multirow{2}{*}{$\begin{array}{l}\text { Номер бджолиних } \\
\text { сімей }\end{array}$} & \multicolumn{3}{|c|}{ Дати підрахунку запечатуваного розплоду } & \multicolumn{2}{|c|}{$\begin{array}{c}\text { Кількість вирощеного розплоду в } \\
\text { середньому по двох датах підрахунку }\end{array}$} \\
\hline & & $\mathrm{I}$ & II & III & по сім'ях & по групі \\
\hline \multirow{5}{*}{ Контрольна } & 43 & 2170 & 2245 & 2050 & 2147 & \multirow{5}{*}{$2225,0 \pm 40,81$} \\
\hline & 2 & 2300 & 2350 & 2141 & 2245 & \\
\hline & 17 & 2280 & 2270 & 2301 & 2285 & \\
\hline & 81 & 2230 & 2265 & 2002 & 2133 & \\
\hline & 12 & 2280 & 2340 & 2290 & 2315 & \\
\hline \multirow{5}{*}{ Дослідна } & 18 & 2214 & 2375 & 2430 & 2402 & \multirow{5}{*}{$2528,6 \pm 44,50 * *$} \\
\hline & 4 & 2230 & 2470 & 2527 & 2498 & \\
\hline & 6 & 2354 & 2460 & 2802 & 2631 & \\
\hline & 10 & 2190 & 2470 & 2717 & 2593 & \\
\hline & 22 & 2310 & 2407 & 2631 & 2519 & \\
\hline
\end{tabular}

Примітка: **-P $<0,01$

Водночас, необхідно відмітити, що у бджолиних сімей дослідної групи, яких стимулювали підгодівлею глюкозо-фруктозним сиропом, інтенсивність вирощення розплоду була вірогідно вищою на 13,6 \% (P < 0,01), порівняно з їх аналогами із контрольної групи, і становила $2528,6 \mathrm{~cm}^{2}$.

Таким чином, підгодівля бджіл в умовах закритого грунту глюкозо-фруктозним сиропом дає можливість підвищити кількість вирощеного ними розплоду, що сприятиме вищій чисельності бджіл у сім'ї.
Здатність бджіл збирати квітковий пилок з різних видів рослин упродовж всього сезону проявляється у флороміграції і свідчить про широку трофічну пластичність сім’ї як біологічної одиниці, що автономно живиться в природному середовищі. Особливе значення, як товарна продукція, має монофлорне бджолине обніжжя. Підгодівля медоносних бджіл в умовах закритого грунту глюкозо-фруктозним сиропом, на фоні наявності в гніздах в достатній кількості кормового меду та перги, позитивно вплинула на кількість зібраної обніжки (табл. 3).

\section{Таблиця 3}

Вплив підгодівлі бджіл глюкозо-фруктозним сиропом на кількість зібраної обніжки, $\bar{X} \pm S_{\bar{X}}, \mathrm{n}=5$

\begin{tabular}{|c|c|c|c|}
\hline \multirow{2}{*}{ Група бджолиних сімей } & \multirow{2}{*}{ Номер бджолиних сімей } & \multicolumn{2}{|c|}{ Відібрано бджолиного обніжжя, г } \\
\hline & & по сім'ях & по групі \\
\hline \multirow{5}{*}{ Контрольна } & 43 & 20,0 & \multirow{5}{*}{$26,9 \pm 3,17$} \\
\hline & 2 & 27,5 & \\
\hline & 17 & 34,0 & \\
\hline & 81 & 20,8 & \\
\hline & 12 & 32,0 & \\
\hline \multirow{5}{*}{ Дослідна } & 18 & 29,0 & \multirow{5}{*}{$32,3 \pm 1,83$} \\
\hline & 4 & 33,5 & \\
\hline & 6 & 30,5 & \\
\hline & 10 & 30,2 & \\
\hline & 22 & 38,1 & \\
\hline
\end{tabular}


Одержані результати показали, що бджолині сім’ї дослідної групи мали найвищу пилкову продуктивність 32,3 г, що на 20,1 \% вище, ніж аналогічний показник у контрольній групі. Таким чиним, стимулююча підгодівля бджолиних сімей глюкозо-фруктозним сиропом в умовах закритого грунту сприяла підвищенню збору бджолами пилку з огірків, що свідчить про вищу інтенсивність їх запилення.

\section{Висновки}

Стимулююча підгодівля бджолиних сімей глюкозо-фруктозним сиропом із розрахунку 200 г на добу в умовах закритого грунту, на фоні наявності в гніздах у достатній кількості кормового меду та перги, сприяє підвищенню кількості вирощеного ними розплоду на $13,5 \%$ ( $<<0,01)$ та кількості принесеного ними пилку 20,1 \%. Враховуючи одержані результати досліджень необхідно відмітити, що в умовах ізольованого простору, кількість вирощеного розплоду, тобто майбутня пилкова продуктивність сімей, буде залежати не тільки від наявності у вулику кормів, а й від підгодівлі бджіл рідким вуглеводним корм (глюкозофруктозним сиропом) 3 оптимально збалансованим спектром цукрів.

\section{References}

Bilash, N. G. (2005). Korma i kormoproizvodstvo v pchelovodstve. Sbornik nauchno-issledovatel'skih rabot po pchelovodstvu. Rybnoe: FGBNU "NII pchelovodstva", 156-163 (in Russian).

Blonskaja, V. N., Guba, P. A., \& Dvoreckij, A. I. (1990). Medonosnye rastenija Ukrainy. Dnepropetrovsk. DGU (in Russian).

Chergyk, M. I., Harchenko, P. A., \& Bondarchuk L. U. (1972). Vykorystannja bdzhil na zapyleni sil's'kogospodars'kyh roslyn. Kyi'v. Urozhaj (in Ukrainian).

Drobot, V. I., Syl'chuk, T. A., Udvorgeli, L. I., Bondarenko, Ju. V., \& Talanov O. B. (2006). Gljukozno-fruktoznyj syrop - perspektyvnyj natural'nyj zaminnyk cukru. Hranenye y pererabotka zerna, 9, 38-39 (in Ukrainian).

Drujbiak, A., Mironovich, A., Kovalska, L., \& Kovalskyi, Y. (2017). Pollen analysis included rectum of honey bees. Scientific Messenger of LNU of Veterinary Medicine and Biotechnologies. Series: Agricultural Sciences, 19(79), 135-139. Retrieved from https://nvlvet.com.ua/index.php/agriculture/article/vie w/2795.

Druzhbjak, A. J. (2013). Zagodivlja ta stymuljacija bdzholynyh simej. Bdzholjar, 9, 18-20 (in Ukrainian).

Kovalchuk, I., Dvylyuk, I., Lecyk, Y., Dvylyuk, I., \& Gutyj, B. (2019). Physiological relationship between content of certain microelements in the tissues of different anatomic sections of the organism of honey bees exposed to citrates of argentum and cuprum. Regulatory Mechanisms in Biosystems, 10(2), 177181. doi: 10.15421/021926.
Kovalskyi, Yu., Gucol, A., Gutyj, B., Sobolev, O., Kovalska, L., \& Mironovych, A. (2018). Features of histolism and hystogenesis in the vital temperature range in the organism of honey bee (Apis mellifera L.) in the postembrional period. Ukrainian Journal of Ecology, 8(2), 301-307. doi: 10.15421/2018_342.

Nedashkivskyi, V. M., \& Hutsol, H. V. (2020). The effectiveness of using protein mixed feed in feeding honey bees. Ukrainian Journal of Veterinary and Agricultural Sciences, 3(1), 34-37. doi: 10.32718/ujvas31.06.

Nedashkivs'kyj, V. M. (2017). Efektyvnist' zastosuvannja u bdzhil'nyctvi gljukozo-fruktoznogo syropu (GFS42). Tehnologija vyrobnyctva i pererobky produkcii' tvarynnyctva: zbirnyk naukovyh prac'. Bila Cerkva, 12(134), 66-70 (in Ukrainian).

Piven, O. T., Khimych, M. S., Salata, V. Z., Gutyj, B. V., Naidich, O. V., Skrypka, H. A., Koreneva, Z. B., Dvylyuk, I. V., Gorobey, O. M., Rud, V. O. (2020). Contamination of heavy metals and radionuclides in the honey with different production origin. Ukrainian Journal of Ecology, 10(2), 405-409. doi: 10.15421/2020_117.

Plokhynskyi, N. A. (1969). Rukovodstvo po byometryy dlia zootekhnykov. Moskva. Kolos (in Russian).

Polishhuk, V. P., \& Gajdar, V. A. (2008). Pasika. Kyi'v. Perfekt Stajl (in Ukrainian).

Ponomareva, E. G. (1980). Kormovaja baza pchelovodstva y opыlenyja sel'skohozjajstvennyh rastenyj. Moskva. Kolos (in Russian).

Prudnikov, V. G. (2017). Efektyvnist' riznyh sposobiv pidgotovky bdzholynyh simej do zymivli. Naukovyj visnyk Nacional'nogo universytetu bioresursiv i pryrodokorystuvannja Ukrai'ny. Serija: Tehnologija vyrobnyctva i pererobky produkcii' tvarynnyctva, 271, 244-248 (in Ukrainian).

Razanov, S. F., Nedashkivs'kyj, V. M., \& Kovka, N. S. (2019). Ocinka efektyvnosti vykorystannja riznyh vuglevodnyh kormiv u godivli bdzhil. Godivlja tvaryn ta tehnologija kormiv: zbirnyk naukovyh prac'. Vinnycja. 5(108), 29-34 (in Ukrainian).

Razanov, S. F., Nedashkivs'kyj, V. M., \& Razanov, O. S. (2018). Osnovy tehnologii' vyrobnyctva produkcii' bdzhil'nyctva. Vinnycja. Nilan (in Ukrainian).

Taranov, G. F. (1986). Korma y kormlenye pchel. Moskva. Rossel'hozyzdatel'stvo (in Russian).

Vishchur, V. Y. Saranchuk, I. I., \& Gutyj, B. V. (2016). Fatty acid content of honeycombs depending on the level of technogenic loading on the environment. Visnyk of Dnipropetrovsk University. Biology, ecology, 24(1), 182-187. doi: 10.15421/011622.

Vishchur, V. Y., Gutyj, B. V., Nischemenko, N. P., Kushnir, I. M., Salata, V. Z., Tarasenko, L. O., Khimych, M. S., Kushnir, V. I., Kalyn, B. M., Magrelo, N. V., Boiko, P. K., Kolotnytskyy, V. A., Velesyk, T., Pundyak, T. O., \& Gubash, O. P. (2019). Ef-fect of industry on the content of fatty acids in the tissues of the honey-bee head. Ukrainian Journal of Ecology, 9(3), 174-179. doi: 10.15421/2019_727. 